\title{
Knowing Teaching Poetically
}

\author{
Aaron Zimmerman, Linnie Greenlees, Elizabeth Isidro, and Stacey Sneed
}

\begin{abstract}
In this article, we present a set of poems that have helped us to come to know teaching in particular ways. We argue that the artistic medium of poetry can provide unique and important insights into what it is like to live through classroom moments. Using connoisseurship as our mode of inquiry, we share these poems, our interpretations of these poems, and our justification for why poetry is a valid way of knowing teaching. We invite our readers to join us in exploring the aesthetic dimension of teaching.
\end{abstract}

\section{Background}

In this article, we present a set of poems that have helped us to come to know teaching in particular ways. We believe that the knowledge that we have gained from these poems is, indeed, just as (if not more) truthful than the knowledge about teaching that we have learned through standardized, empirically verified data sources (cf. Muijs \& Reynolds, 2018). Although empirical research may present us with useful conceptual frameworks for how teaching and learning works (cf. Ambrose, Bridges, DiPietro, Lovett, \& Norman, 2010), such research does not necessarily present us with lifelike portraits of what it is like to experience teaching and learning (van Manen, 2014). While it may be important to know, conceptually, which pedagogical practices produce the largest gains in student achievement (cf. Marzano, 2003), it is, we argue, equally important for scholars and practitioners to know, affectively, what it can be like to live through moments of teaching in real classrooms, in real time, alongside real human beings. Teachers must recognize and be responsive to the mood of the classroom if they are to exercise pedagogical sensitivity and tact (Garcia \& Lewis, 2014; van Manen, 2007; van Manen \& Li, 2002).

We believe that, too often, teachers overlook—or disregard — the affective qualities that characterize their experiences in classrooms, in part because policymakers and administrators tend to prioritize the measurable and controllable aspects of teaching above all else (Bengtson \& Connors, 2014; Brown \& Weber, 2016; Timberlake, Thomas, \& Barrett, 2017). We believe that poetry is one way to illuminate teachers' hidden understandings and "to reveal what [previously] had not been noticed" (Barone \& Eisner, 1997, p. 102). In order to explore this thesis, we present three poems and explore the unique insights that these poems have afforded us as practitioners and scholars of teaching. As we share these poems and our justification for why poetry is a valid way of knowing teaching, we invite our readers to consider the prospect that there is an aesthetic dimension to teaching and that this dimension can be deeply revealed through aesthetic, poetic perception. 


\section{Aesthetic Perception and Connoisseurship}

The arts reveal the qualitative nature of human experience (Barone \& Eisner, 1997; Belanger, 1998; Eisner, 2002, 2006). Moments are characterized through moods (Heidegger, 1962), and, if we attune ourselves to these moods, we may be able to appreciate the aesthetic qualities of our everyday experience (Dewey, 1934). As Sinclair (2009) writes, "the aesthetic does not describe the qualities of perceptual artifacts; rather, [the aesthetic] characterizes experiences...Aesthetic experiences can be had while appreciating art, while fixing a car, while having dinner, or while solving a mathematics problem" (p. 50).

When we solve everyday problems (whether fixing a car or preparing a meal), we do so by employing rationality but also by discerning the aesthetics—or affect—of the given moment, namely, by responding to "what is felt emotionally" (Eisner, 2002, p. 76; see also Anderson, 2014). In this way, we engage in the world both cognitively and affectively, and our aesthetic perception helps us, in particular, to "pay attention to matters of...the way qualities are configured" (Eisner, 2002, p. 85). By appreciating the particular quality of an experience, we are able to tune ourselves to what is actually happening in the given moment (Heidegger, 1962; Küpers, 2002; Schön, 1983; van Manen, 2007).

Given that noticing and appreciating the aesthetic dimension of our experience helps us to better understand our world and our experience, the arts can be understood to be a representation of this aesthetic perception (Dewey, 1934; Eisner, 2002). In this way, the arts signify a particular way of knowing, and one way to curate this knowledge is through connoisseurship (Eisner, 2003, 2017; Uhrmacher, Moroye, \& Flinders, 2017). Connoisseurship is a holistic method of qualitative inquiry that invites researchers to pay close attention to aesthetic perceptions and to argue for how and why these perceptions have implications for how we engage in the world (Brinkmann, 2014; Kaysi, Bavli, \& Gurol, 2017; Kelehear, 2008). In this context, the researcher makes explicit value judgments and functions as

an artistic critic, attending closely to the "appreciation of qualities" (Eisner, 2017, p. 66) and making these appreciations public. In other words, the role of the critic or connoisseur is to reeducate one's audience so that one's audience is better able to perceive a given work of art. Within this mode of inquiry, the validity of the connoisseur's work rests in the extent to which others are able to appreciate a work of art with a newfound richness.

\section{Poetry as Art and Data}

Although the method of connoisseurship can be applied to any aesthetic medium, in this article, we choose to focus, in particular, on the understandings uniquely revealed through poetry. Poetry is a particularly powerful medium through which to explore the realities of teaching, given that effective poetry is able to capture the ineffable qualities of a real-life moment in time: "Poems, surrounded by space and weighted by silence, break through the noise to present an essence...[Poems capture] heightened moments of social reality as if under a magnifying glass" (Leavy, 2009, p. 63). 
Knowing teaching through poetry, therefore, is more than simply describing a classroom situation; rather, poems are able to capture evocative portraits of intense, singular moments of human interaction with the world (Gold, 2013; Prendergast, 2009; Richardson, 1998). Thus, poetry focused on teaching can "work through a different set of issues" (Leavy, 2009, p. 64) than alternative representations of teaching in which the aim is to describe teaching with as much generalization as possible (cf. Ambrose et al., 2010; Lemov, 2010; Marzano, 2003). While having an abstracted, generalized understanding of teaching serves a purpose, poetry can help practitioners and scholars refocus on the empathic and evanescent features of the classroom (van Manen \& Li, 2002). In other words, poetry can sharpen a teacher's aesthetic perception.

Using the method of connoisseurship, we will present three poems and argue that these poems reveal important dimensions in/of teaching. These poems, thereby, function as data that manifest truths. How can the truthfulness of these poems be evaluated? Adhering to the role of the connoisseur, we ask our readers to evaluate for themselves whether or not "the poem [s] call forth something from your [own] experience" (Leavy, 2009, p. 82). In other words, the poems-and our respective interpretations-should be considered to be truthful if, and only if, they feel truthful (see Faulkner, 2005; Richardson, 2000; Bochner, 2000).

\section{"Love in the Classroom" by Al Zolynas}

Afternoon. Across the garden, in Green Hall, someone begins playing the old piano a spontaneous piece, amateurish and alive, full of a simple, joyful melody.

The music floats among us in the classroom.

I stand in front of my students telling them about sentence fragments. I ask them to find the ten fragments in the twenty-one-sentence paragraph on page forty-five.

They've come from all parts of the world - Iran, Micronesia, Africa, Japan, China, even Los Angeles - and they're still eager to please me. It's less than half way through the quarter.

They bend over their books and begin. Hamid's lips move as he follows the tortuous labyrinth of English syntax. Yoshie sits erect, perfect in her pale make-up, legs crossed, quick pulse minutely jerking her right foot. Tony, from an island in the South Pacific, sprawls limp and relaxed in his desk.

The melody floats around and through us in the room, broken here and there, fragmented, re-started. It feels mideastern, but 
it could be jazz, or the blues - it could be

anything from anywhere.

I sit down on my desk to wait,

and it hits me from nowhere - a sudden

sweet, almost painful love for my students.

"Never mind," I want to cry out.

"It doesn't matter about fragments.

Finding them or not. Everything's

a fragment and everything's not a fragment.

Listen to the music, how fragmented,

how whole, how we can't separate the music

from the sun falling on its knees on all the greenness,

from this movement, how this moment

contains all the fragments of yesterday

and everything we'll ever know of tomorrow!"

Instead, I keep a coward's silence.

the music stops abruptly;

they finish their work,

and we go through the right answers,

which is to say

we separate the fragments from the whole.

(Zolynas, as quoted in Milosz, 1996, pp. 193-194).

Perhaps the most remarkable feature of this poem is the way that the poet is able to juxtapose the profundity of his unfolding lived experience with the banality of the prescribed exercises from the textbook. The bodies of the students, the distant sound of the music, and his strong feeling of love are unmistakably more compelling than the "twenty-one-sentence paragraph on page forty-five." The significance he felt being revealed through body, time, space, and relationship were, however, minimized and relegated as he chose to prioritize the prescribed grammar lesson. This poem illustrates how meaningful moments in the classroom may unexpectedly reveal themselves through moodsincluding moods of pleasure, appreciation, love, and awe-and that these fleeting moods cannot necessarily be found within textbooks or academic exercises.

Commenting on his own poem, Zolynas (2011) writes,

I've once in a while found myself in those gifted moments when the presence of my students has unexpectedly been bathed in sweet light, indeed, when Love was suddenly present. Here, I'm not speaking of that warm and sappy thing we sometimes mistake for Love, but...the thing that can bring us to our knees if we allow it...that moment of sacred reverence and wholeness. (p. 1)

The poem, thus, teaches us that moments of profundity are available to teachers if teachers surrender to profound moments as they appear; however, the inclination to prioritize government mandated subject matter outcomes over lived experience sabotages these revelations. When teachers regard textbooks and lesson plans as more real than their own intuition and affect, teachers may be hijacking the flow of their own experience (Garcia \& Lewis, 2014; Latta \& Field, 2005; Uhrmacher, Moroye, \& Conrad, 2016). 


\section{"I Can Hear You" by Korrine Patterson}

I can hear you

Do you?

I am sitting here

In this chair

Trying my best or at least I was

Are you?

You ask me questions

That I do not know

But still you don't wait for me to answer

You talk to fast

And you don't even check to see if I'm ready

You tell me to take notes

But still I don't

When I'm quiet I am good

But when I'm noisy I am bad

You always tell me what to do

Write this or write that

It doesn't matter

You have already decided that I can't hear you

You have decided that I can't understand

But I can

I can hear you

I can understand

Maybe I can't understand every concept

But I do understand your tone

I understand that your weekend

is more important then me

I understand your data sheet

Is more valuable then me

I can hear you

When you talk about your child, your weekend camping trip

Or how you say some of us just aren't getting it

I can hear you

I know that student is me

I know and

I can hear you

(Patterson, 2017).

It is vitally important that teachers not make assumptions about the abilities of their students with diverse learning needs (Cook, Tankersley, Cook, \& Landrum, 2000; Kliewer \& Biklen, 2001; Naraian, 2008). Instead of making assumptions, it is critical that teachers cultivate engaging, supportive, and trust-based relationships with their students (Alton-Lee, 2003; McNeilly, Macdonald, \& Kelly, 2015). Unless these relationships are cultivated, students may experience a deep sense of isolation (Cornelius-White, 2007; Koller, LePouesard, \& Rummens, 2018; Kunter et al., 2013; Margalit, 2010).

Patterson's poem presents these conclusions from the first-person perspective of a student who is being ignored and unappreciated by her teacher. The speaker in this poem challenges teachers to examine the affective impact of their discourse and manner of interaction in the classroom (see also Bostic, 2014; 
Fenstermacher, 2001; Kraker, 2000). This poem narrates the struggle of not being heard, seen, or understood by one's teacher, the very person who is supposed to provide the student with support and encouragement:

You have already decided that I can't hear you

You have decided that I can't understand

But I can

Presenting this experience through the aesthetic medium of poetry heightens the intensity of this frustration. In doing so, this poem reminds us of the impact that both teachers' actions (and inactions) can have on students and that when teachers prioritize their own agenda above students' sense of self-worth, resentment may be bubbling beneath the surface.

By giving us insight into what our students might be experiencing, this poem has the potential "to reveal [to teachers] what [previously] had not been noticed" (Barone \& Eisner, 1997, p. 102). In this way, this poem has inherent instructional potential in the context of teacher education and teacher development. Specifically, by illuminating the hidden quality of a particular student's experience, this poem may compel teachers to reflect on the extent to which they are emotionally supporting each student in their classroom. Although (only) an artistic representation, this poem supports us in our efforts to know and hear our students.

\section{"Man Can Never Know the Rain" by Taylor Mali}

Man can never know the rain even if he swears

he can understand the thunder.

That is not the same as knowing water, where it comes from, where it runs, or what it takes with it when it goes,

when one stream flows into another, then a river, a sea and the ocean, which never even needs to whisper

Let yourself come into me

Men will never know the rain or how to make it come when it is calledit is only ever chance when clouds appear

to answer to the dancers and the dance.

A man can only ride out the rain.

Or cast his moon-face to the sky,

let himself be washed in it. Close his eyes

and pray, Please come wash over me

without washing me away.

(Mali, 2014, p. 17) 
Carl Sandburg (1978) suggested that, "What can be explained is not poetry" (p. 27). Likewise, Mali's poem compels us to challenge our epistemological assumptions about teaching: What does it mean to know teaching? Can teaching ever be understood? If we aspire to explain teaching, are we depriving ourselves of experiencing teaching's poetic dimension? Perhaps, as Mali's poem suggests, one can never know teaching, just as one can never know the rain.

Despite their ardent efforts, generations of educational psychologists and educational reformers have been unable to engineer learning (Biesta, 2007; Fendler, 2012; Gottlieb, 2012). Even when teachers employ best practices with fidelity, educative moments may or may not manifest themselves in the classroom. Akin to our inability to summon the rain, we do not fully know "how to make [learning] come when it is called." Instead, there always exists some measure of uncertainty (Dudley-Marling, 1997) and risk (Biesta, 2014) during a pedagogical act.

Mali's poem suggests that in order to experience the wonder of our world, we need only open ourselves to wonder. In the context of education, understanding teaching is not a prerequisite to experiencing it. Being open to the present moment is necessary and sufficient (Macdonald \& Shirley, 2009; Srinivasan, 2014).

Mali's poem encourages us to be willing "to answer" the call "when clouds appear" and to "let [ourselves] be washed in" the magic of meaningful moments. Of course, teaching is also an incredibly complex and challenging act, where cognitive overload and emotional exhaustion are always possibilities. Thus, Mali also gifts us with a useful prayer: to pray that teaching washes over us without washing us away.

\section{The Implications (and Risks) of Knowing Teaching Poetically}

Poetry can elevate even seemingly mundane observations. Ordinary features of the classroom (such as students' postures or sunlight through a window) may be classified as extraneous when curriculum is positioned as the premier goal of teaching; but, through poetry, we are reminded to appreciate the significance of everyday moments. The "sun falling on its knees on all the greenness" is just as (if not more) meaningful than the "twenty-one-sentence paragraph on page forty-five." We believe that engagement with poetry can move scholars and practitioners closer towards integrating their intellectual, emotional, and aesthetic understandings of what it means to be a teacher.

If poetry represents a unique (if not vital) way of knowing teaching, important implications follow. For example, rather than asking teachers to broaden their professional knowledge exclusively through the studying of content knowledge (e.g., Van Driel \& Berry, 2012) or by practicing specific pedagogical skills (e.g., Supovitz \& Turner, 2000), efforts in teacher education and teacher development might ask teachers to sharpen their aesthetic perception of the classroom by reflecting on the classroom poetically. Indeed, research has found that novice and experienced teachers alike benefit from the reading and writing of poetry (Certo, Apol, Wibbens, \& Hawkins, 2012; Davis, 2014; Rosaen, 2003). Exploring teaching in arts-based ways can help teachers come to know what effective and tactful 
(as well as ineffective and insensitive) teaching feels like from the perspective of both teachers and students (Eisner, 2004, 2006).

However, insisting that personal, emotional, and aesthetic insights can serve as knowledge, can be risky within contexts that insist that teaching should be measurable (Brown \& Weber, 2016) and rooted in evidence-based practices (Ball \& Forzani, 2009). As Behar (2008) writes,

Poetry...[is] the larger desire to speak from a deeper part of the self...[it] is the thing that we...thirst for but feel we can't, or rather shouldn't, admit we desire... To long for poetry is to cast doubt on our commitment to maintaining the sobriety and respectability...of the university system. To long for poetry... is to be immature, self-centered. To long for poetry is to risk losing it all. (p. 60)

In other words, despite the poet's "desire to speak from a deeper part of the self," some policymakers and educational leaders may have different expectations as it pertains to being a successful teacher and educational researcher. Teachers need to help students to pass standardized tests (Thibodeaux, Labat, Lee, \& Labat, 2015; Valli \& Buese, 2007), and faculty members need to publish generalizable, empirical research (Creps, 2018; Redman-MacLaren, 2015). Sometimes, teaching quality and scholarly significance is assessed according to measurable impact, rather than affective resonance.

To explore this tension further, we close with a poem written by one of the authors of this manuscript:

The child who refuses to complete the task, Lying his head down in silent protest.

The disobedient and disrespectful type

Who doesn't understand the rules of life.

Then there is the student who understands the game,

What needs to be done and finished today.

The logical and reasonable student type

The one who understands the rules of life.

The two children presented in this poem represent our dualities: expert and novice; teacher and student; scholar and practitioner; academic and poet. Of course, these dualities are not mutually exclusive dichotomies; rather, they are reciprocal, dialogical dimensions of our professional identity. We, too, "understand the game." We know "what needs to be done and finished today." We recognize that our responsibilities as educators sometimes require more than being "immature, [and] self-centered." Yet, simultaneously, if cultivating spaces of inclusive and equitable education necessitates knowing teaching in multiple ways, then it is also our responsibility, as educators, to listen to our own poetic voice and to the poetic voices of our colleagues and students. As Eisner (2002) writes, the hallmark of the aesthetic experience is "the ability to surrender to the qualities of [what] one beholds" (p. 88). Poetry encourages us to allow ourselves to surrender to what we see, hear, and feel. When we tap into our poetic understanding of teaching, we pray for wonder and for the courage to accept this wonder as knowledge. 
As we venture into our poetic imaginations, we risk losing our grip on predictability. We make ourselves vulnerable to encountering the world in new ways. We now leave it in the hands of our readers to decide whether or not this is a risk that they themselves are willing to take. We can account for ourselves: Knowing teaching poetically is vital, because, for us, "What's at stake in the work [of knowing teaching poetically] is never just an intellectual exercise but [the exploration of] knowledge that is essential, knowledge that [we] couldn't live without" (Behar, 2008, p. 69).

\section{References}

Alton-Lee, A. (2003). Quality teaching for diverse students in schooling: Best evidence syntheses. Wellington: Ministry of Education.

Ambrose, S. A., Bridges, M. W., DiPietro, M., Lovett, M. C., \& Norman, M. K. (2010). How learning works: 7 research-based principles for smart teaching. San Francisco, CA: Jossey-Bass.

Anderson, B. (2014). Encountering affect: Capacities, apparatuses, conditions. London: Routledge.

Ball, D., \& Forzani, F. (2009). The work of teaching and the challenge of teacher education.

Journal of Teacher Education, 60(5), 497-511. doi:10.1177/0022487109348479

Barone, T., \& Eisner, E. (1997). Arts-based educational research. In J. Green, G. Camilli, \& P. Elmore (Eds.), Complementary methods in research in education (pp. 95-109). Mahwah, NJ:

Lawrence Erlbaum.

Behar, R. (2008). Between poetry and anthropology: Searching for languages of home. In CahnmannTaylor \& R. Siegesmund (Eds.), Arts-based research in education: Foundations for practice (pp. 55-71). New York, NY: Routledge.

Belanger, S. L. (1998). Knowing through art. In W. Braud \& R. Anderson (Eds.), Transpersonal research methods for the social sciences: Honoring human experience (pp. 166-168). Thousand Oaks, CA: SAGE.

Bengtson, E., \& Connors, S. P. (2014). Puppets and puppeteers: External mandates and the instructional practice of two first-year teachers. International Journal of Educational Leadership Preparation, 9(2), $128-152$.

Biesta, G. (2007). Why "what works" won't work: Evidence-based practice and the democratic deficit in educational research. Educational Theory, 57(1), 1-22.

Biesta, G. (2014). The beautiful risk of education. Boulder, CO: Paradigm Publishers.

Bochner, A. (2000). Criteria against ourselves. Qualitative Inquiry, 6, 278-291.

Bostic, T. B. (2014). Teacher empathy and its relationship to the standardized test scores of diverse secondary English students. Journal of Research in Education, 24(1), 3-16.

Brinkmann, S. (2014). Getting in touch with the world: Meaning and presence in social science. In M. H. Jacobsen, M. S. Drake, K. Keohane, \& A. Petersen (Eds.), Imaginative methodologies in the social science: Creativity, poetics and rhetoric in social research (pp. 133-154). Farnham: Ashgate. 
Brown, C. P., \& Weber, N. B. (2016). Struggling to overcome the state's prescription for practice: A study of a sample of early educators' professional development and action research projects in a high-stakes teaching context. Journal of Teacher Education, 67(3), 183-202.

Certo, J. L., Apol, L., Wibbens, E., \& Hawkins, L. K. (2012). Living the poet's life: Using an aesthetic approach to poetry to enhance preservice teachers' poetry experiences and dispositions. English Education, 44(2), 102-146.

Cook, B. G., Tankersley, M., Cook, L., \& Landrum, T. J. (2000). Teachers attitudes toward their included students with disabilities. Exceptional Children, 67(1), 115-135.

Cornelius-White, J. (2007). Learner-centered teacher-student relationships are effective:

A meta-analysis. Review of Educational Research, 77(1), 113-143.

Creps, K. B. (2018). Get published, now: An introduction to qualitative education research. Qualitative Inquiry. doi:1077800418767205.

Davis, D. E. (2014). Using the "right poem" to raise sociocultural consciousness. The Educational Forum, 78(4), 421-431.

Dewey, J. (1934). Art as experience. New York, NY: Capricorn Books.

Dudley-Marling, C. (1997). Living with uncertainty: The messy reality of classroom practice. Portsmouth, NH: Heinemann.

Eisner, E. W. (2002). The arts and the creation of mind. New Haven, CT: Yale University Press.

Eisner, E. W. (2003). Educational connoisseurship and educational criticism: An arts-based approach to educational evaluation. In T. Kellaghan \& D. L. Stufflebeam (Eds.), International handbook of educational evaluation (pp. 153-166). Dordrecht, Netherlands: Springer.

Eisner, E. W. (2004). What can education learn from the arts about the practice of education? International Journal of Education \& the Arts, 5(4), 1-13.

Eisner, E. W. (2006). Does arts-based research have a future? Studies in Art Education, 48(1), 9-18.

Eisner, E. W. (2017). The enlightened eye: Qualitative inquiry and the enhancement of educational practice. New York, NY: Teachers College Press.

Faulkner, S. L. (2005). How do you know a good poem? Poetic representation and the case for criteria. Symposium conducted at the First International Conference of Qualitative Inquiry, Urbana-Champaign, Illinois.

Fendler, L. (2012). The magic of psychology in teacher education. Journal of Philosophy of Education, $46(3), 332-351$.

Fenstermacher, G. (2001). On the concept of manner and its visibility in teaching practice. Journal of Curriculum Studies, 33(6), 639-653.

Garcia, J. A., \& Lewis, T. E. (2014). Getting a grip on the classroom: From psychological to phenomenological curriculum development in teacher education programs. Curriculum Inquiry, 44(2), 141-168. 
Gold, K. (2013). A space for stories: Revisiting relational poetry as inquiry on everyday practice. Qualitative Social Work, 12, 849-857.

Gottlieb, D. (2012). Beyond a rule-following model of skillful practice in teacher development. Educational Theory, 62(5), 501-516.

Heidegger, M. (1962). Being and time (J. Macquarrie \& E. Robinson, Trans.). New York, NY: Harper Perennial.

Kaysi, F., Bavli, B., \& Gurol, A. (2017). Educational connoisseurship and criticism: Evaluation of a cooperation model between university and the sector on vocational education. Journal of Education and Practice, 8(6), 25-35.

Kelehear, Z. (2008). Instructional leadership, connoisseurship and critique: Using an arts-based approach to extend conversations about teaching. International Journal of Leadership in Education, $11(3), 239-256$.

Kliewer, C., \& Biklen, D. (2001). School's not really a place for reading: A research synthesis of the literate lives of students with severe disabilities. Journal of the Association for Persons With Severe Handicaps (JASH), 26(1), 1-12.

Koller, D., Le Pouesard, M., \& Rummens, J. A. (2018). Defining social inclusion for children with disabilities: A critical literature review. Children \& Society, 32(1), 1-13.

Kraker, M. (2000). Classroom discourse: Teaching, learning, and learning disabilities. Teaching and Teacher Education, 16(3), 295-313.

Kunter, M., Klusmann, U., Baumert, J., Richter, D., Voss, T., \& Hachfeld, A. (2013). Professional competence of teachers: Effects on instructional quality and student development. Journal of Educational Psychology, 105(3), 805-820.

Küpers, W. (2002). Phenomenology of aesthetic organising: Ways towards aesthetically responsive organizations. Consumption, Markets and Culture, 5(1), 21-46.

Latta, M. M., \& Field, J. C. (2005). The flight from experience to representation: Seeing relational complexity in teacher education. Teaching and Teacher Education, 21, 649-660.

Leavy, P. (2009). Method meets art: Arts-based research practice. New York, NY: Guilford Press.

Lemov, D. (2010). Teach like a champion: 49 techniques that put students on the path to college. San Francisco, CA: Jossey-Bass.

Macdonald, E., \& Shirley, D. (2009). The mindful teacher. New York, NY: Teachers College Press.

Mali, T. (2014). Bouquet of red flags. Austin, TX: Write Bloody Publishing.

Margalit, M. (2010). Lonely children and adolescents: Self-perceptions, social exclusion, and hope. New York, NY: Springer.

Marzano, R. J. (2003). What works in schools: Translating research into action. Alexandria, VA: Association for Supervision and Curriculum Development.

McNeilly, P., Macdonald, G., \& Kelly, B. (2015). The participation of disabled children and young people: A social justice perspective. Child Care in Practice, 21(3), 266-286. 
Milosz, C. (Ed.). (1996). A book of luminous things: An international anthology of poetry. Orlando, FL: Harcourt.

Muijs, D., \& Reynolds, D. (2018). Effective teaching: Evidence and practice (4th ed.). Los Angeles, CA: SAGE.

Naraian, S. (2008). Institutional stories and self-stories: Investigating peer interpretations of significant disability. International Journal of Inclusive Education, 12(5-6), 525-542.

Patterson, K. (2017). I can hear you.

Retrieved from https://www.poetrysoup.com/poem/i_can_hear_you_892459

Prendergast, M. (2009). "Poem is what?" Poetic inquiry in qualitative social science research. International Review of Qualitative Research, 1(4), 541-568.

Redman-MacLaren, M. (2015). Becoming a researcher: An auto-ethnographic account of a doctoral researcher re-presented in poetry. Journal of Poetry Therapy, 28(3), 207-214.

Richardson, L. (2000). Evaluating ethnography. Qualitative Inquiry, 6, 253-255.

Richardson, M. (1998). Poetics in the field and on the page. Qualitative Inquiry, 4, 451-462.

Rosaen, C. L. (2003). Preparing teachers for diverse classrooms: Creating public and private spaces to explore culture through poetry writing. Teachers College Record, 105(8), 1437-1485.

Sandburg, C. (1978). Early moon. New York, NY: Harcourt, Brace \& World.

Schön, D. A. (1983). The reflective practitioner: How professionals think in action. New York, NY: Basic Books, Inc.

Sinclair, N. (2009). Aesthetics as a liberating force in mathematics education? ZDM, 41(1-2), 45-60.

Srinivasan, M. (2014). Teach, breathe, learn: Mindfulness in and out of the classroom. Berkeley, CA: Parallax Press.

Supovitz, J. A., \& Turner, H. M. (2000). The effects of professional development on science teaching practices and classroom culture. Journal of Research in Science Teaching, 37(9), 963-980.

Thibodeaux, A. K., Labat, M. B., Lee, D. E., \& Labat, C. A. (2015). The effects of leadership and highstakes testing on teacher retention. Academy of Educational Leadership Journal, 19(1), 227-249.

Timberlake, M. T., Thomas, A. B., \& Barrett, B. (2017). The allure of simplicity: Scripted curricula and equity. Teaching and Teacher Education, 67, 46-52.

Uhrmacher, P. B., Moroye, C. M., \& Conrad, B. (2016). Aesthetic, spiritual, and flow experiences:

Contrasts and educational implications. Education and Culture, 32(1), 131-151.

Uhrmacher, P. B., Moroye, C. M., \& Flinders, D. J. (2017). Using educational criticism and connoisseurship for qualitative research. New York, NY: Routledge.

Valli, L., \& Buese, D. (2007). The changing roles of teachers in an era of high-stakes accountability. American Educational Research Journal, 44(3), 519-558. 
van Driel, J. H., \& Berry, A. (2012). Teacher professional development focusing on pedagogical content knowledge. Educational Researcher, 41(1), 26-28.

van Manen, M. (2007). Phenomenology of practice. Phenomenology \& Practice, 1(1), 11-30.

van Manen, M. (2014). Phenomenology of practice: Meaning-giving methods in phenomenological research and writing. Walnut Creek, CA: Left Coast Press.

van Manen, M., \& Li, S. (2002). The pathic principle of pedagogical language. Teaching and Teacher Education, 18, 215-224.

Zolynas, A. (2011). On "love in the classroom". Serving House Journal, 3, 1-2.

doi:http://www.servinghousejournal.com/ZolynasTalksLove.aspx\#ZolynasCommentary.
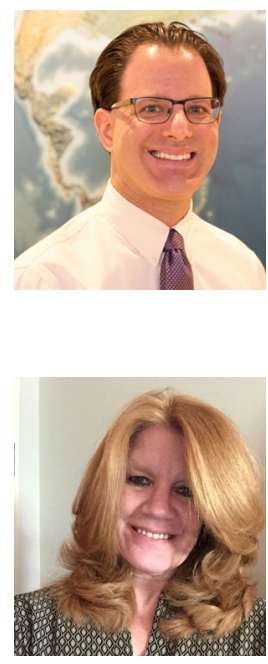

Aaron Zimmerman is an Assistant Professor of Curriculum and Instruction in the College of Education at Texas Tech University. He studies experiences of becoming a teacher and experiences of becoming a teacher educator. He currently teaches courses introducing students to scholarship in teacher education and to methods of educational research. He received his PhD in Curriculum, Instruction, and Teacher Education from Michigan State University.

Linnie Greenlees is an Assistant Professor of Practice and the Curriculum Anchor for special education in the Department of Teacher Education at Texas Tech University. Dr. Greenlees is a passionate advocate for students with diverse learning needs and a strong proponent for equitable and inclusive education. Her research focuses on inclusive school reform, collaborative teacher education, situated learning, and teacher identity as a predictor of attrition. Dr. Greenlees is currently designing undergraduate teacher education coursework with an emphasis on specialized instruction and differentiation for diverse learners across the content areas.

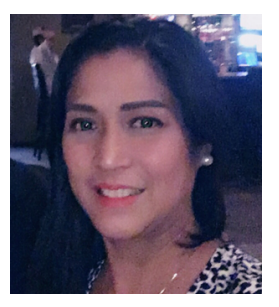

Elizabeth Isidro is an Assistant Professor in Literacy Studies at the Department of Special Education and Literacy Studies in Western Michigan University. Aside from her faculty role, she serves as the Director of the McGinnis Reading Center and Clinic, also housed in the same university. Among her research interests are applications of reader response theory in teaching as well as arts-based methodologies as alternative forms of research.

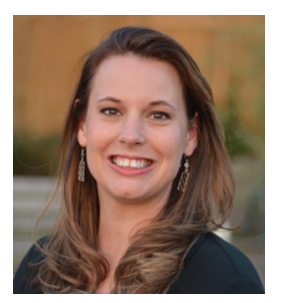

Stacey Sneed is a third-year PhD student and Helen DeVitt Jones Fellow in Curriculum and Instruction at the College of Education at Texas Tech University. Prior to attending Texas Tech University, she worked for 10 years as a middle school science teacher. Her research focus is on preservice teachers' use of inquiry-based teaching and science education. 